\title{
II 。弾性波デバイスを用いた化学センサ
}

\author{
正員 塩川祥子(静岡大学工学部光電㙨晠工学科) \\ 正員 森 泉 豊 栄 (東京工業大学電気電子工学科)
}

\section{1.はじめに}

アイクロプロセッサを中心とする情報処理手段の発 展に伴い，気体中や溶液中の分子種や分子濃度を検出 する化学センサの電子デバイス化の研究が活発に行わ れている。小型化, 高速化, 多機能化を目指した化学 センサとして現在, 半導体デバイス, 光デバイス, そ して超音波デバイスを用いるものがある。いずれも検 知対象分子が表面・界面に吸着し, 物理的, 化学的変 化を起し，この変化を電気信号として出力している。本 稿では、これらの中で超音波技洼である弾性波デバイ スを用いた化学センサの原理と応用例について解説を 行う。

弾性波デバイスはフィル夕、共振器などの電子デバ イスとして重要な役割をもっている。その理由は, 弾 性波の波長が電磁波の波長の約 $10^{-5}$ 倍であることが 電子部品の小型化に結びついているからである。最近 では, 高品質・高密度化の電子部品の要求に伴って, 波のエネルギーが表面付近に集中した表面波（SAW） を用いた高周波デバイスの発展がめざましい。

弾性波デバイスの化学センサへの応用は1959年に 水晶バルク振動子の電極上での物質吸着が発振周波数 の変化として検出できることが見いだされたことから 開始された(1)。この物質吸着による周波数変化は発振 周波数の 2 乗に比例するので，高周波デバイスである SAW デバイスを化学センサに応用することが 1979 年Wohltjen らにより行われた ${ }^{(2)}$ 。更にバイオセンサ への応用を目指し，溶液系 SAW センサの開発が現在 活発に行われている(5)。また，七ンシング面上の コーティンク膜の種類が異なる多数個の水晶振動子七 ンサを同時に用いて，それらの出力をパターン処理す るにおい識別システムの開発が行われている(6)。これ

II. Chemical Sensor Using Acoustic Wave Devices.

By Showko Shiokawa, Member (Shizuoka University) \& Toyosaka Moriizumi, Member (Tokyo Institute of Technology) $\neq-7-ト:$ QCM, SAW, SH-SAW, SH-APM, Lamb 波, 水晶振動子, 弹性表面波, 粘性奻果, 電気音粼相互作用

電学諭C, 111 巻 9 号, 平成 3 年
は今後のセンサの発展方向として重要である。

\section{2. 弾性波デハイスを用いた化学センサの種類}

弾性波デバイスは用いる励振モードにより分類する のが一般的であり，表 1 に弾性波化学センサの種類を 分類してみた。横欄に大きくバルク波と表面波の 2 種 類に分けられることを示した。バルク波としては，(1) QCM(Quartz Crystal Microbalance), SAW として は, (2) R-SAW (Rayleigh Surface Acoustic Waves), (3) SH-SAW (Shear Horizontal SAW), (4) SH-APM (Shear Horizontal Acoustic Plate Mode), (5) Lamb 波, の4 種類がある。SAW の中で, (4) SH.APM と (5) Lamb 波は基板の上面と下面を反射面とする板波 であり，表面波ではないが，ここではSAWの中にい れた。SAWのように表面に沿って波動が伝搬し， IDT (Interdigital Transducer) が励振に使われるた め，類似のデバイスと見なされることが多いためであ る。

表中にそれぞれの振動モードの概略図を示した。(1) のQCM は厚みすべり振動を用いるため気相系，液相 系両方に用いることができる。(2)のR-SAW デバイ スでは変位が波の進行方向と, 基板に垂直方向成分か らなり，垂直偏波している。垂直成分が原因で液体中 にエネルギーを放射する。従って気相のみで用いられ る。(3) O SH-SAW は, 波の進行方向に蕉直で, 基板

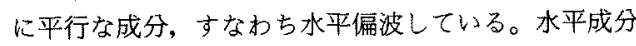
は液体との界面ですべりながら伝搬するので液相で用 いることができる。(4)のSH-APM は，SHタイプな ので液相で用いることができる。また板波なので電極 IDTがない方の面をセンシングに使うことができる。 (5)の Lamb 波洁 Rayleigh 型の板波であるが，板の厚 みが非常に薄くなると液体の音速より小さい位相速度 となり，液体中にエネルギ一を放射しなくなる。この ような条件の Lamb波を用いれば溶液系センサとな る。これらいずれのセンサに扔いても, 増幅器を電極 間に摷入することにより発振回路が構成され，表面上 で物質吸着が発振周波数の変化として検出される。 


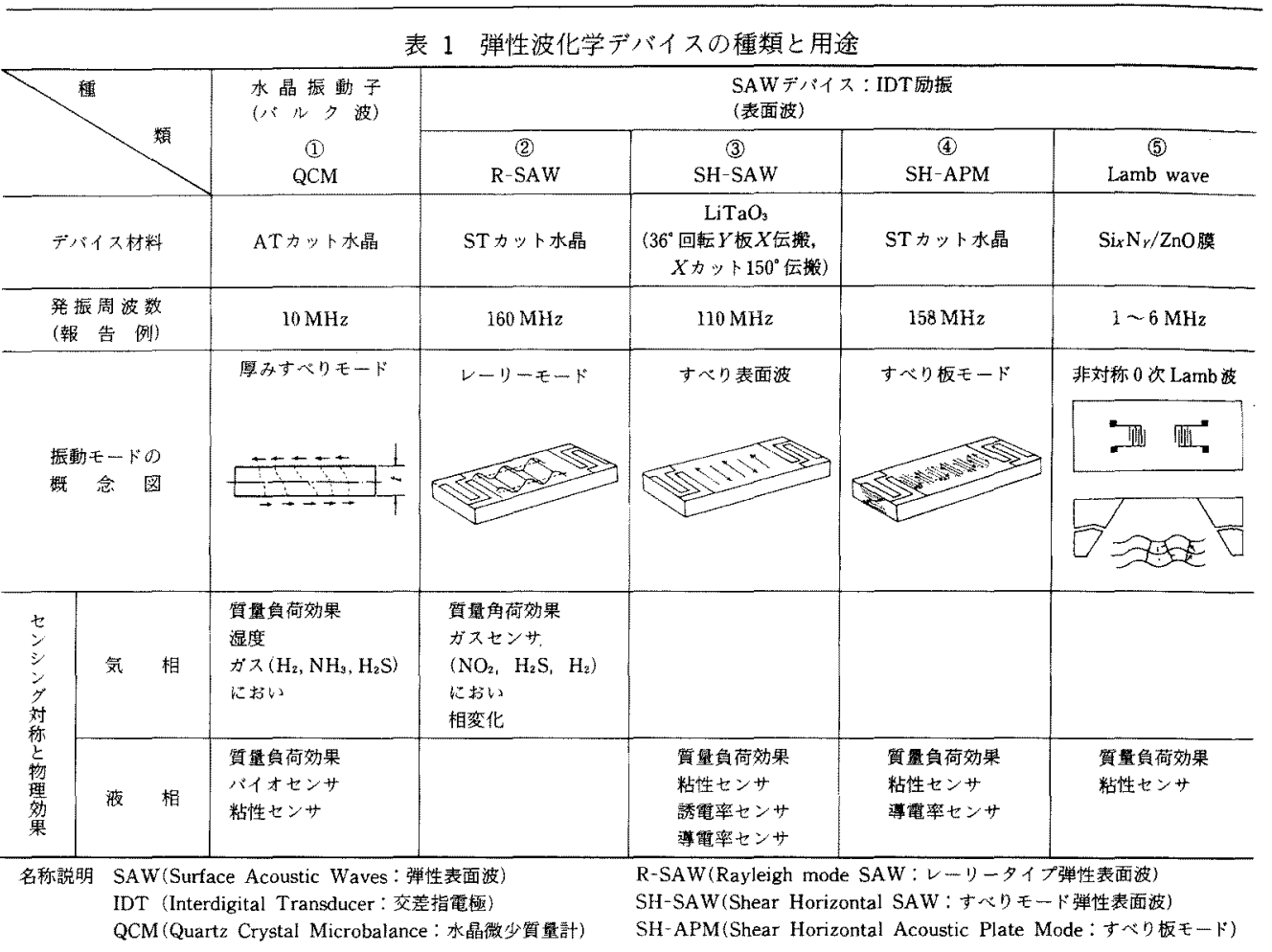

この周波数变化 $\Delta f$ は発振周波数の 2 乗に比例するた め高周波化が容易な SAW デバイスの方がバルク振動 子より大きな周波数変化を得ることが期待できる。

(1)，(4)，(5)のデバイスは板の厚さが振動周波数に直 接関伱し，高周波化のためには板を薄くしなければな らない。一方, (2), (3)のSAW デバイスはIDTの周 期で周波数が決定されるため, 周波数の限界はIDT 電極作製技術と発振の女定性により決定される。

これらの弾性波デバイスを用いた化学センサに扔い て分子検出の選択性结表面コーティング膜の物理的 化学的選択性に依存している。コーティングの方法と しては現在, ディップ法, スプレー法, スピナー法, LB 膜法などがある。膜材料の研究とコーティング法 の研究は弹性波化学センサの今後の発展に重要である が本稿では省略する。

\section{3. 水晶振動子}

\section{1 センシングの原理}

水晶振動子を用いた蒸着膜の膜厚計は Sauerbrey ${ }^{(1)}$ により提案されて以来, 広く使うれている。その原理 は, 振動子の表面に質量が負荷されたとき, その共振
周波数が低下する現象，いわ加る質量解荷効果 mass loadingである。この効果は膜厚計以外にも種々の応 用がある。分子吸着に対して選択性を持つ膜を振動子 表面に付着させて扝けば化学センサが得られる。空気 中で水蒸気やガス分子を检知するセンサについては King(7) ${ }^{(7)}$ Guilbault ${ }^{(8)}$ が，溶液中で使用するセンサに ついては Thompson ${ }^{(9)}$ や村松(10) の研究がよく知られ ている。

また振動子表面上では，振動に伴って流体分子が引 きずられ，振動の減衰と同時に実効的な質量負荷効果 をもたらし，共振周波数が低下する。これを粘性効果 viscosity effectという。この粘性効果を用いたセン サの試みは Kanazawa ${ }^{(11)}$ ，筆者(12)などにより行われ ている。

水晶振動子センサの物質吸着による発振周波数の変 化について Sauerbery は振動子の共振周波数の基本 式より次の式を導いた ${ }^{(1)}$ 。

$$
\frac{\Delta f}{f}=\frac{\delta t}{t}=-\frac{\Delta M}{\rho A t}=-\frac{\Delta M f}{\rho A N}
$$

ここて, $f$ : 基本周波数, $\Delta f:$ 周波数変化, $t$ : 振動 子の厚さ, $\Delta M$ : 重量変化, $\rho:$ 水晶の密度, $A$ : 振 
動子の面積， $N$ : 振動子の周波数定数である。

(1) 式は吸着量 $\Delta M$ が $\rho A t$ に対して十分小さい場 合に成り立つ。しかし, 気相, 腹相に坊ける分子の吸 着, 膜形成, 粘性などのセンシングの応用に対する統 一的理墖も必要である。筆者らは Masonの等価回路 に基つきき包括的な理諭展開を行った ${ }^{(13)}$ 。以下にその 要点を示す。

\section{2 等価回路による理論}

AT カット水晶バルク振動子の表面は, 表面に平行 に振動している。従って，振動子が種々の媒体と接触 する場合は，媒体の横波インピーダンスを計算し，こ れをMason 等洒回路の音響端子につなぎ，電気端子 からみたインピーダンスを計算すれば，振動子の共振 特性変化が求められる。

以下に三つの場合につき結果を示す。

（a）薄膜を負荷した場合膜厚計のように振 動子表面に薄膜（厚さ $h$, 等方体) が負荷され, 薄膜 が薄い場合 (1)式の結論と同しになり，愿い場合には 次の近似式が得られた。

$$
\Delta f=-f \frac{\rho^{\prime} h}{\rho t}\left\{1-\frac{\pi^{2}}{8} \frac{\rho^{\prime} h}{\rho t}+\frac{1}{3}\left(2 \pi f \frac{h}{V^{\prime}}\right)^{2}\right\}
$$

ここで, $\rho と \rho^{\prime}$ は水晶と膜の密度, $t$ は水晶板の厚 さ，V'は膜の横波速度である。

（b）粘性流体を負荷した場合液体を負荷し た合，粘性により液体中に横波が励振されるが、これ は界面から急速に隇衰する波である。この場合の共振 周波数の変化は

$$
\Delta f=-f \frac{\rho_{1} \lambda_{2}}{\rho t}
$$

となるが，ここで， $\rho_{i}$ は液体の密度， $\lambda_{l}=\sqrt{\frac{\eta}{2 \omega \rho_{l}}}$ は 粘性侵入度と呼ばれ横波が液体中に侵入する深さ（） はずれ粘性係数)である。（3）式と（1）式を比較すれ ば， $\lambda_{l}$ の厚さの液が振動子に䨘量負荷された結果, 周波数変化が起ることがわかる。

(c) 溶液中で膜成長が行われる場合電着や免 疫センサの上うに溶液中で膜成長や吸着反応のため質 量変化が起きる場合, 膜が薄く粘性による効果も小さ いなら，近似的に

$$
\Delta f=-f\left(\frac{\rho^{\prime} h}{\rho t}+\frac{\rho_{l} \lambda_{l}}{\rho t}\right)
$$

となり，質量負荷と粘性効果が加算される。

(4)式は電着膜の析出をモニ夕する場合などには妥 当であろう。

\section{SAW デパイス}

\subsection{R-SAW およひSH-SAW デバイスのセンシ ングの原理と理論}

SAWデバイスはIDT電極間の伝搬面上への分子吸 着あるいは粘性による伝搬速度の変化を発振周波数の 変化として検出する。SAW センサの構成を図 1 に示す。

SAW の伝搬速度は運動方程式, マックスウエルの 方程式および压電基本式を用いて Campbell \& Jones ${ }^{(14)}$ の方法により数值的に求めることができる。 しかし伝搬面上の雲囲気に上る速度变化は，変化のな い場合を基準とした提動法からも得ることができる。 筆者らはAuldによって示された伝搬定数 $\beta$ の摄動式 $\Delta \beta$ を毛とにしてセンサの特性を求めた ${ }^{(15)}$ 。ここで， $\beta$ は波数 $k$ 扝よび隇衰 $\alpha$ より次式で定義される。

$$
\beta=k-j \alpha \text {. }
$$

これより $\Delta \beta$ は次式となる。

$$
\Delta \beta^{\prime}=\frac{\Delta \beta}{k}=-\frac{\Delta V}{V}-j \frac{\Delta \alpha}{k}=-\frac{\Delta f}{f}-j \frac{\Delta \alpha}{k}
$$

ここで，Vは伝搬速度であり，両辺を波数で規格化 し， $\Delta \beta^{\prime}$ と扔いた。摂動法の特徵は機械的摄動と電気 的摄動を分けて扱える点である。機械的摂動および電 気的摄動解を以下に示す。

（1）液体中の機械的摄動 図 2 に示すような粘 性率 $\eta$, 密度 $\rho_{l}$, 体積弹性率 $k$ の液体中で密度 $\rho^{\prime}$,

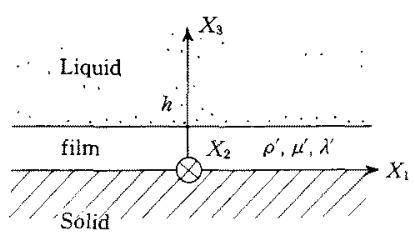

図 2 溶液中質量負荷の座標系

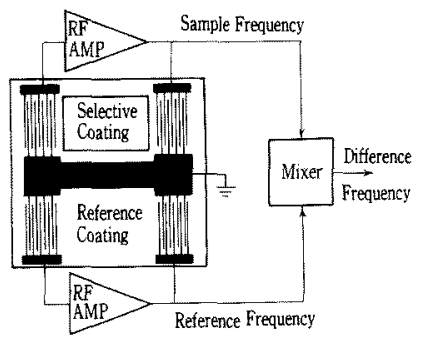

図 1 SAW センサの構成 
膜厚 $h$ 等方性薄膜が伝搬面上に負荷されることに より生じるSHモードの捸動を考える。ただし $\mu^{\prime}, \lambda^{\prime}$ 㹥争荷膜の Lamè 定数である。伝搬面は電気的に短 絡状態にある。境界条件は $x_{3}=h$ で応力, 粒子速度 が連続となる。負荷膜と液体中の基本式より $x_{3}=0 て ゙$ の応力の提動量を求める。

(a) 粘性効果 SHモードであることを考慮する と, 速度変化と隇衰変化は次式で表わされる。

$$
\begin{aligned}
& \frac{\Delta V}{V}=-\frac{V}{4 \omega P} \sqrt{\frac{\omega \rho_{l} \eta}{2}} v_{2}^{2} \\
& \frac{\Delta \alpha}{k}=\frac{V}{4 \omega P}\left[\sqrt{\frac{\omega \rho_{t} \eta}{2}} v_{2}^{2}+\sqrt{\rho_{l} k-\frac{k^{2}}{V^{2}}} v_{3}^{2}\right]
\end{aligned}
$$

ここで $v_{2}, v_{3}$ は $x_{2}, x_{3}$ 軸方向の粒子速度である。 (7)式中 $v_{3}$ の二乗項は SHモードにわずかに存在す る垂直偏波成分による伝搬損である。Pは単位幅の パワーフロー。

（b) 質量負荷効果質量負荷前後で粘性による 音篦的変化がないと仮定すると

$$
\begin{aligned}
\Delta \beta^{\prime}= & \frac{V \cdot h}{4 P}\left\{\left(\rho^{\prime}-\frac{1}{V^{2}} \frac{4 \mu^{\prime}\left(\lambda+\mu^{\prime}\right)}{\lambda+2 \mu^{\prime}}\right) v_{1}^{2}\right. \\
& \left.+\left(\rho^{\prime}-\frac{\mu^{\prime}}{V^{2}}\right) v_{2}^{2}+\rho^{\prime} v_{3}^{2}\right\} \ldots \ldots \ldots \ldots
\end{aligned}
$$

となる。この式で $v_{2}=0$ とした場合はR-SAWにおけ る質量負荷効果の式と一致する(16)。

（2）電気的摄動（音響電気相互作用）空気負 荷での電気的摄動を求めたAuldの式をもとにした。液 体中では導電率 $\sigma$ と比誘電率 $\varepsilon_{r}$ をパラメータとする複 素誘電率 $\varepsilon_{l}$ を導入し，これを次式のように定義した。

$$
\varepsilon_{l}=\varepsilon_{r} \varepsilon_{0}-j \sigma / \omega
$$

捸動前の基準状態として導電率 0 の液体を選ぶ。これ が提動により

$$
\varepsilon_{l}^{\prime}=\varepsilon_{r}{ }^{\prime} \varepsilon_{0}-j \sigma / \omega
$$

となる。これらのパラメー夕を用いて電気的掫動を求 めた結果が(11)式である。

$$
\begin{aligned}
& \frac{\Delta V}{V} \simeq\left(\frac{\Delta V}{V_{0}}\right)_{l s c} \frac{\omega^{2} \varepsilon_{0}\left(\varepsilon_{r}^{\prime}-\varepsilon_{r}\right)\left(\varepsilon_{r}^{\prime} \varepsilon_{0}+\varepsilon_{P}^{T}\right)+\sigma^{2}}{\sigma^{2}+\omega^{2}\left(\varepsilon_{r}^{\prime} \varepsilon_{0}+\varepsilon_{P}^{T}\right)^{2}} \\
& \frac{\Delta \alpha}{k} \simeq-\left(\frac{\Delta V}{V_{0}}\right)_{l s c} \frac{\sigma \omega\left(\varepsilon_{r}^{\prime} \varepsilon_{0}+\varepsilon_{P}^{T}\right)}{\sigma^{2}+\omega^{2}\left(\varepsilon_{r}^{\prime} \varepsilon_{0}+\varepsilon_{P}^{T}\right)^{2}}
\end{aligned}
$$

ここで, $\left(\frac{\Delta V}{V_{0}}\right)_{l s c}$ は水負荷時の基板責が short, open $の$ 速度变化率, $\varepsilon_{P}^{T}=\sqrt{\varepsilon_{11}^{T} \varepsilon_{33}^{T}-\left(\varepsilon_{31}^{T}\right)^{2}}$ は伝搬方向 の奏効誘電率である。

4.2 SH-APM およびLamb 波デバイスの原理 無限平板を伝搬する波動は複雑であるが代表的な 2
種類の板波がある。一つは粒子変位が板面に平行で, かつ波動の伝搬方向と直行するもので水平偏波をする $\mathrm{SH}$ 波，他の一つは Lamb 波といわれ縦波と横波が結 合した波である。Lamb 波は一般に板波といわれ，こ の横波は粒子変位の方向が波の進行方向に直角で，か つ板面にも直角な垂直偏波である。SH-APM が溶液 系センサとして用いられる理由は ATカット水晶や SH-SAW と同じ水平偏波をしているからである。一 方，Lamb 波は表面で R-SAW と同じ偏波なので一般 的には水中へエネルギーを放射するが，その伝搬速度 が水中縦波音速より遅い場合には非放射となる。非対 称 0 次モードにおいて（周波数×板厚）の值が非常に 小さい場合このような条件を満たすことができる。

これらのモードで問題になるのは分散性である。例 えばLamb 波非対称の0次モードの場合は，板厚に よる速度変化が大さいためIDT 共振周波数の制御が 困難であり，加えて板厚自体も薄く（膜に近い）製作 自体も蜼しい。それに対して R-SAW と SH-SAW は 速度分散性がなく，IDT 周期により設計周波数を決 めることができる。SH-APM ではST-水晶を用いた Martin \& Ricco ${ }^{(4)} の ，$ Lamb 波で $\mathrm{Si}_{x} \mathrm{~N}_{y} / \mathrm{ZnO}$ 粠造 のWhite ${ }^{(5)}$ の研究が良く知られている。STカット $X$ 伝搬水晶は弾性表面波励振用素子であるが, ST-水 昆の板波について Houが理論および実験を示してい $ろ^{(18)(19)}$ 。SH-APM およびLamb波デバイスの質量 負荷効果执よび粘性効果，更にはSH-APMにおける 電気音響相互作用の理論式についてはそれぞれ文献 (4)，(5)に導かれている。それを以下に示す。

(1) SH-APM

(a) 質量負荷効果

$$
\frac{\Delta f_{n}}{f_{n}}=-\frac{J_{n}}{\rho t} \rho^{\prime} h
$$

ここで $\rho:$ 水晶の密度, $t:$ 板厚, $\rho^{\prime}, h:$ 負荷膜の密 度括よび膜固, $n$ はモードの番号

$$
\begin{aligned}
J_{n} & =1 / 2(n=0) \\
& =1 \quad(n=1, \cdots)
\end{aligned}
$$

(b) 粘性効果

$$
\begin{aligned}
& \frac{\Delta f_{n}}{f_{n}}=-\frac{c_{v}}{2 \omega} \sqrt{\omega \rho_{l} \eta} \\
& \alpha=\frac{c_{v}}{2 V_{n}} \sqrt{\omega \rho_{l} \eta}
\end{aligned}
$$

ここで, $V_{n}$ は位相速度, $V_{B n}$ は群速度, $c_{v}=\frac{V_{n}}{V_{g n}} \frac{J_{n}}{\rho t}, \rho_{l}, \eta$ : 液体の密度および粘性

(c) 電氛一音響相互作用これはSH-SAWで導 かれた式(11)式と等しい。 
(2) Lamb 波

\section{(a) 質量負荷効果}

$$
\frac{\Delta f}{f}=-\frac{\rho^{\prime} h}{2\left(\rho t+\rho_{l} \delta_{p}\right)}
$$

ここで, $\delta_{p}=\lambda /\left(2 \sqrt{1-V / V_{l}}\right), V_{l}:$ 液体の音速であり, $\rho_{l} \delta_{\rho}$ は液体負荷による実効的な質量の増加を表わし ている。 $\rho$ は板（実際は膜のように薄い）の平均密度。

(b) 粘性効果

$$
\begin{aligned}
& f=\frac{1}{\lambda}\left\{\frac{B}{\rho t+\rho_{l} \delta_{p}+\left(\frac{\rho_{l} \eta}{2 \omega}\right)^{1 / 2}}\right\}^{1 / 2} \\
& \alpha=\frac{(\pi f)^{1 / 2}}{4 \rho t V}\left(\frac{v_{1}}{v_{m}}\right) \sqrt{\rho_{l} \eta}
\end{aligned}
$$

ここで， $v_{m}$ は板モードの平均粒子速度， $v_{1}$ は板に平 行な成分の粒子速度, $B$ は板の実効スチフネス。 $\left(\rho_{l} \eta / 2 \omega\right)^{1 / 2}$ は粘性侵入度内の粘性による実効的な質 量増加を表わしている。

\section{3 溶液系センサの感度比較}

$\mathrm{AT}$ カット水晶バルク振動子, Lamb波, SH APM，そして SH-SAW を用いた溶液系センサの感 度比較を行う。測定ではセンサを発振系に組み込むの

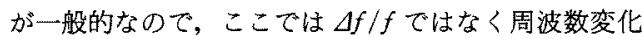
$\Delta f$ を用いて比較した。その結果を表 2 に示す。水晶 振動子と SH-SAW は, 質量負荷は $f^{2}$ に, 粘性は $f^{3 / 2}$ に比例している。係数の相違は，振動モードと材料定 数の違いを表わしている。また，水晶振動子の係数が

\begin{tabular}{|c|c|c|}
\hline & 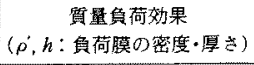 & $\begin{array}{c}\text { 粘性効果 } \\
\left\langle\rho_{l,}, 7: \text { 液体の密度·粘性 }\right\rangle\end{array}$ \\
\hline $\begin{array}{l}\text { 水晶振動子 } \\
(\mathrm{AT} \text {-水晶 })\end{array}$ & $\Delta f=-2.26 \times 10^{-\prime} \cdot \rho^{\prime} h \cdot f^{2}$ & $\Delta f=-4.17 \times 10^{-8} \cdot \sqrt{\rho_{l} \eta} \cdot f^{3 / 2}$ \\
\hline $\begin{array}{c}\text { SH-SAW } \\
\text { (36YX.LT) }\end{array}$ & $\Delta f=-3.30 \times 10^{-8} \cdot \rho h \cdot f^{2}$ & $\Delta f=-9.30 \times 10^{-9} \cdot \sqrt{\rho_{l} \eta \eta^{*}} f^{3 / 2}$ \\
\hline
\end{tabular}
SAW デバイスより 1 けた大きいことがわかる。従つ

表 2 溶液系弾性波デバイスの特性

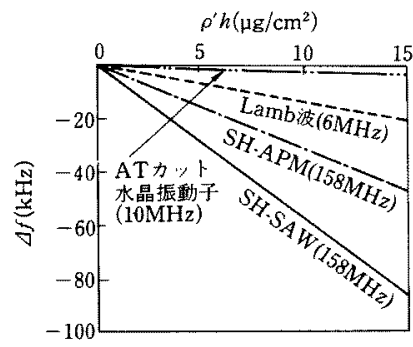

図 3 溶液系弾性波デバイスの質量負荷特性 の比較 (理論)
てSAW デバイスはかなり高い周波数で用いなければ 水晶振動子を上回る特性を得ることができない。

SH-APM とLamb 波は速度分散性のため周波数依 存性を直接式で表わせない。そこで，励振周波数を報 告されている最高の值 (ATカット水晶バルク振動 子：10 MHz, Lamb 波: $6 \mathrm{MHz}$, SH-APM : 158 $\mathrm{MHz}$, ここでは SH-SAW $158 \mathrm{MHz}$ とした）とし て，質量負荷効果に詨する $\Delta f$ を比較した。結果を図 3 に示卞。

また，電気音響相互作用はSH-SAW とSH-APM デバイスのみで可能である。周波数変化と減衰は(11) 式で求められているが，圧電材料の $K^{2}\left(=\frac{2 \Delta V}{V}\right) に$ 比例するため， $\mathrm{LiTaO}_{3}$ 基板を用いる $\mathrm{SH}-\mathrm{SAW} か ゙$ 水 晶のSH-APM より1けた大きな感度をもっている。

\section{5. センサの具体例}

SAW センサの具体例として筆者らの提案する $\mathrm{SH}$ SAW デバイスのセンサ諸特性拉よび水晶振動子アレ イを用いた「においセンサ」を紹介する。

\subsection{SH-SAW 溶液系センサ}

筆者らはSHタイプの弾性表面波として電気機械結 合係数 $K^{2}$ が $4.7 \%$ と大く，遅延時間温度係数も $-33 \mathrm{ppm} /{ }^{\circ} \mathrm{C}$ と小さい $36^{\circ}$ 回転 $Y$ 板 $X$ 伝搬 $\mathrm{LiTaO}_{3}$ (以下 36 YX. LT と格記) を用いている(20)

$36 \mathrm{YX}$. LT 基板を用いたデバイスは，図 4 に示さ れるような送受IDT と伝搬面からなる表面波伝般遅 延線を 2 組並列に配した構成になっている。液体の粘 性効果と液体中の質量負荷効果を测定する場合には, 図 4(a)に示されるように伝搬面を $\mathrm{Cr} / \mathrm{Au}$ で short にした。音響電気相互作用測定に用いたデバイスは 図 4(b)に示されるように2 組の遅延線のうち一方の 一部を openとした。粘性効果, 質量負荷効果測定時 は伝搬面のどちらか一方をりファレンス面，他方をセ ンシング面とし，音響電気相互作用では short 側をり ファレンス面，open 側をセンシング面とした。発振 器からの信号を送波両IDTに入力し，それぞれの受

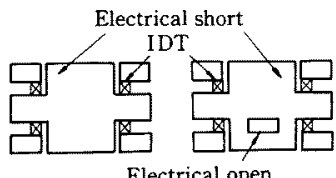

(a) 機械的㼡動用パターン (b) 電気的摄動用パターン

図 4 SH-SAW センサパターン

電学論C，111 巻 9 号, 平成 3 年 


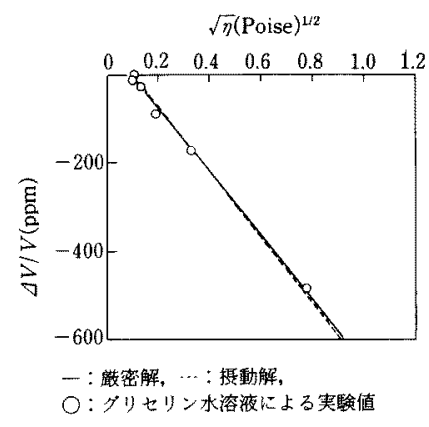

図 5 SH-SAW センサの粘性特性

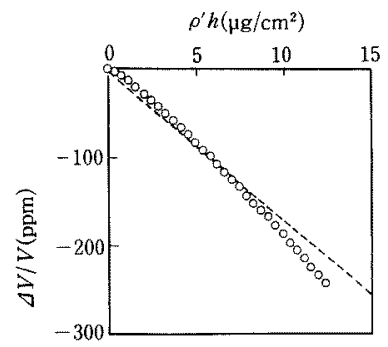

提動解，○：銅めつきによる実験值

図 6 SH-SAW センサの質量負荷特性

波IDT からの出力信号をベクトルボルトメータに取 り込む位相差法で測定を行った。また同時に振幅を測 定した。

(1) 機械的摄動

（a）液体の粘性効果試料溶液としてグリセり ン水溶液を用い，その濃度を変えることにより粘性率 を変化させた。励振周波数を $51 \mathrm{MHz}$, 基準溶液を水 としたときの理論と測定結果を図 5 に示す。

(b)液体中の質量負荷効果液体中で筫量負 荷効果を調べるため, $0.75 \mathrm{M} \mathrm{CuSO}_{4} / 0.75 \mathrm{M} \mathrm{H}_{2} \mathrm{SO}_{4}$ 水溶液中 $\left(21.5^{\circ} \mathrm{C}\right)$ で銅めっきを行った。センシン グ面の $\mathrm{Cr} / \mathrm{Au}$ を陰極とし，陽極として純銅板を使用

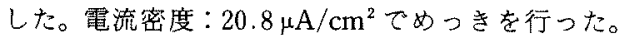
測定值と摂動解を図 6 に示す。

(2) 電気一音響相互作用

(a)誘電率に上る変化 水, メ夕ノール, エ夕 ノール, シリコンオイルを用いて誘電率を测定した結 果を図 7 に示す。横軸㹥比誘電率 $\varepsilon_{r}$ である。これら の試料溶液は埒電率が無視できるので, 理論では比誘 電率のみか変化すると仮定して計算した。

(b) 導電率による変化 $\mathrm{KCl}, \mathrm{LiCl}$ 水溶液の導 電率を変えて剆定した結果を図 8 に示す。図は複素平 面で導電率による速度変化と隇衰の変化を同時に示し

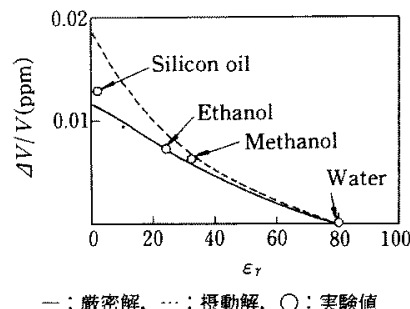

図 7 SH-SAW センサの誘電率特性

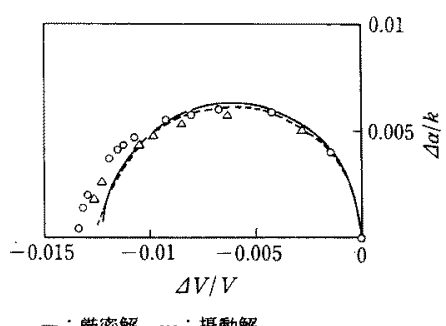

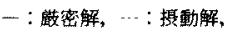

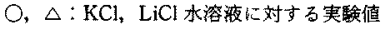

図 8 SH-SAW センサの導電率特性

たものである。理論値は比誘電率を一定 $\left(\varepsilon_{L}{ }^{\prime}=80\right)$ と し，導電率のみが変化するとして計算した。摄動解と

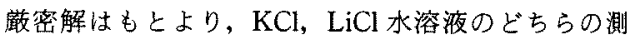
定值もそれぞれ良く一致している。これらのことから 図 4(b)に示すタイプのデバイスは溶液の電気的影響 のみを検出できることが明らかになった。

\section{2 においセンサ}

通常, ガスセンサといえば単一の分子を選択性良く 検出することを目的とする。しかし，においと注 200〜400 種類のにおい分子の集合であるから，にお いセンサの開発にあたってはガスセンサと異なる戦略 が必要と考えられる。筆者らは選択性の低いセンサの 集団的センシングを使うべきと考えた。集団的とは， 一つのセンサが分子のある集団を担当し，別のセンサ が別の集団をセンシングする。多数センサの（これも 集団的）出力パターンを識別すれば，においの種類が 判別できる。

筆者らは，8個の水晶振動子に脂質，セルロース， ガスクロ固定相などの吸着膜を谽り，周波数変化を二 ューラルネットワークによりパターン認識することに より，に扔いを高い正解率で識別できることを示し $た^{(6)}$ 。現在, 洋酒, 飲料, 香水などの工業で行われて いる，人間による官能検査を代替するセンサ系を開発 中である。開発ポイントは膜の選択とセンシングの信 頼性（特にフロー系が重要）の向上であるが，詳細は 
別紙にゆずりたい(21)

\section{6. まとめ}

弾性波を用いた化学センサとして小型, 試料溶液が 少量, 即応性, 高感度といった特徵をもち, 現在研 究・開発が進められている水晶振動子と SAW デバイ スについて解説を行った。

水晶振動子は温度特性に優れ，Qが高いため発振 が非常に安定であり, 既にQCM として気相, 液相中 の膜厚計として広く使用されている。また, 種々の膜 をつけ，ガスセンサ，バイオセンサ，においセンサな どへの応用が開らけつつある。

水晶振動子は基本発振周波数に上限があるため, 更 に高感度なセンサを求めて SAW デバイスの研究が盛 んである。SAW デバイスは確かに高周波デバイスと して GHz オーダまで作製可能で, 理論的には高感度 な質量および粘性センサが得られる。このことを本稿 で示した。しかし高周波になると, 雑音, 干渉などの 高周波回路特有の問題が起り, 更には化学センサにつ きものの伝搬損なども増大する。この問題を解决でき れば SAW デバイスの化学センサへの応用は大き々広 がるであろう。また, 弾性波と表面での分子との相互 作用の問題は新しい分野であり, 化学的・物理的に末 知の問題が多い。今後の課題である。

(平成 3 年 6 月 14 日受付)

\section{文 献}

(1) G. Sauerbrey: Zeitschrift fur Physik, 155, 206 (1959)

(2) H. Wohltjen \& R. Dessy: "Surface Acoustic Wave Probe for Chemical Analysis", Anal. Chem., 51, 9, 1458 (1979)

(3) M. Kuwabara, J. Kondoh, \& S. Shiokawa: "SAW Sensor in Liquid", Technical Digest of 9th Sensor Symp., 177 (1990)

(4) S. J. Martin, A. J. Ricco, T. M. Niemczyk, \& G. C. Frye "Characterization of $\mathrm{SH}$ Acoustic Plate Mode Liquid Sensors", Sensors and Actuators, 20, 253 (1989)

(5) R. M. White \& S. W. Wenzel : "Fluid Joading of a Lamb. wave sensor", Appl. Phys. Letters, 52, 1653 (1988)

(6) T. Nakamoto, K. Fukunishi, \& M. Moriizumi : "Identification Capability of Oder Sensor Using Quartz-Resonator Sensor Array and Neural-network Pattern Recognition", Sensors and Actuators, B1, 473 (1990)

(7) W. H. King: "Piezoelectric Sorption Detector" Anal. Chem., 36, 9, 1735 (1964)

(8) J. Hlavay \& G. G. Guilbault : "Application of the Piezoelectric Crystal Detector in Analytical Chemistry", Anal. Chem., 49, 13, 1890 (1977)

(9) M. Thompson, G. K. Dhaliwal, C. L. Arthur, \& G. S Calabrese: "The Potential of the Bulk Acoustic Wave Device as a Liquid phase Immunosensor", IEEE Trans. Ultrason. Ferro. Freq. Cont., UFFC-34, 2, 127 (1987)

(10) H. Muramatsu, J. M. Dicks, E. Tamiya, \& I. Karube "Piezoelectric Crystal Biosensor Modified with Protein A for Determination of Immunoglobulins", Anal. Chem., 59, 2760 (1987)
(11) K. Kanazawa \& J. G. Gordon: "The Oscillation, Frequency of a Quartz Resonator in Contact with a Liquid", Anal. Chem. Acta, 175, 99 (1985)

(12) T. Nakamoto, K. Inadama, \& T. Moriizumi : "Study on Quartz Thickness-Shear Resonator Immeresed in Liquid and its Biosensor Application", Proc. Acoust. Imaging, p. 619 (1988)

(13) T. Nakamoto \& T. Moriizumi: "A Theory of a Quartz Crystal Microbarance Based upon a Mason Equivalent Circuit", Jpn. J. Appl. Phys., 29, 5, 963 (1990)

(14) J. J. Campbell \& W. R. Jones: "Propagation of Surface Waves at the Boundary Between a Piezoelectric Crystal and a Fluid Medium", IEEE Trans. Sonics and Uitras., SU $-17,2,71(1970)$

(15) B. A. Auld: "Acoustic Fields and Waves in Solids", Vol. 2 Chap. 12 (1973) Jhon Wilely, New York

(16) H. Wohltjen : "Mechanism of Operation and Design Considerations for Surface Acoustic Wave Vapour Sensors", Sensors and Actuators, 5, 307 (1984)

（17）近藤・塩川：「SH-SAW デバイスを用いた溶液系センサ」, 信学技法 SU 9-9 (平 3)

(18) J. Hou: "Approximation Method for Plate Modes in Surface Acousic Wave Devices ", 41st Annual Frequency Control Symp. p. 365 (1987)

(19) J. Hou \& H. Van de Vaat: "Mass Sensitivity of Plate Modes in Surface Acoustic Wave Devices and their Potential an Chemical Sensors", Proc. IEEE Ultras. Symp., p. 573 (1987)

(20) K. Nakamura, M. Kazumi, \& H. Shimizu: "SH-Type and Rayleigh-Type Surface Waves on Rotated Y-cut $\mathrm{LiTaO}_{3}$ " ibid., p. 819 (1977)

(21) A.Fukuda, T. Nakamoto, T. Moriizumi, Y. Asakura, \& Y, Obigane: Technical Digest of The 10th Sensor Sympo. sium., p. 191 (1991)

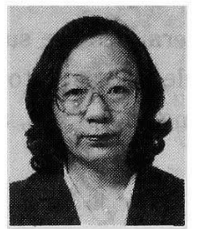

\section{塩川祥子 (正員)}

昭和 40 年 3 月東北大学工学通信工学 科卒業。 43 年 3 月電気通信大学大学院 修士課程修了。46 年 3 月東京工業大学 電気工学科博士課程修了。同年 4 月同大 学助手, 61 年 4 月静岡大学工学部助教授, 平成 3 年 9 月 同教授。工学博士。継電器のチャタリング現象, 弾性表面 波のホログラフィによる観察, 超音波計測系の開発, 光表 面波, バイオ七ンサなどの研究に従事。

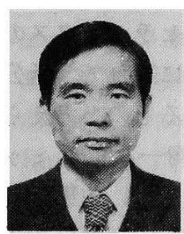

\section{森 泉 豊 栄 (正員)}

昭和 17 年 2 月 19 日生。39年東京工 業大学理工学部電子工学科卒業。4 4 年 同大学院博士課程終了。工学博士。同年 助手。 48 年助教授。 53 年 9 月 54 年 8 月カーネギーメロン大学客員助教授。6 0 年東京工業大学 理工学交流センター教授, 63 年東京工業大学工学部教授 となり現在に至る。この間, 化合物半導体, SAW, 有機 半導体, バイオエレクトロニタスセンサなどの研究に従 事。電子情報通信学会, IEEE, 応用物理学会, 日本音響 学会, 日本 $M E$ 学会, 生物物理学会会員。 